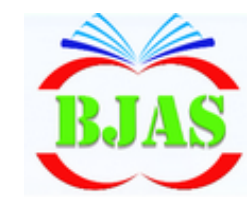

ISSN $1814-5868$
Available online at http://bjas.bajas.edu.iq

https://doi.org/10.37077/25200860.2020.33.2.18 College of Agriculture, University of Basrah

\title{
Effect of Sublethal Concentrations of Cadmium on the Histo-pathological Changes of Muscles of Planiliza abu Juveniles (Heckel, 1843)
}

\author{
Entesar SH. Hashim \& Rajaa N. Al-Yassein \\ Department of Fisheries and Marine Resources, College of Agriculture, University of \\ Basrah, Iraq \\ *Corresponding author: r_alyassein@yahoo.com
}

Received 16 July 2020; Accepted 25 October 2020; Available online 13 November 2020

\begin{abstract}
Water heavy metals contamination is an international issue due to its detrimental impact on the environment, aquatic organisms and impairment of the ecological balance systems. Cadmium is a heavy metal that is extremely toxic, even in low doses, thus it is a big concern to the ecosystem. Cd can cause several Patho-morphological changes in various organs in fish. This study was evaluated the effect of sublethal concentrations of Cd toxicity and effects on Histopathological of muscle tissues of Planiliza abu Juvenile. Series of Cd concentrations $(0.5-2) \mathrm{ppm}$ were used and the $15 \mathrm{~d} \mathrm{LC}_{50}$ was $0.4 \mathrm{ppm}$. Several histopathological alterations were observed which increase gradually with increased concentration, included, marked thickening and hypertrophy of muscle bundle were will observed in lowest concentration $(0.5 \mathrm{ppm})$. While in the highest concentration $(2 \mathrm{ppm})$, atrophy, splitting, and separation with intracellular edema were marked in fish muscle bundle.
\end{abstract}

Key words: Planiliza abu. Cadmium. Sublethal concentrations. Muscles. Histopathology.

\section{Introduction}

Human activities play a big role to increase metal pollution in waters (Popek et al., 2006). Because it is threating aquatic life, available in ecosystem (Abo El Ella et al., 2005) and their persistence in the environment (Biswas et al., 2012). Heavy metals might be entered from different sources such as soil and anthropogenic activities (Abo El Ella et al., 2005) such as, use of fertilizers and pesticides in agriculture and decomposition of organic matter (Bai et al., 2010). Some metals are considered potentially toxic (As, $\mathrm{Cd}, \mathrm{Pb}, \mathrm{Hg}$, etc.), while others are essential $(\mathrm{Cu}, \mathrm{Zn}, \mathrm{Fe}$ and Mn) (Biswas et al., 2012). Cadmium is an extremely toxic metal, even in low doses. It is used in industry specifically in electroplating, industrial paints and batteries (Taylor, 1997). Cd is a natural element nonessential element, due to its ability to transfer, deposition and dissolved within ecosystems, this leads to concerns in terms of accumulation in the aquatic food chain (Guardiola et al., 2013). Cd element and its concentrations have been detected in the air, water, soil, and plants (Amdur et al., 1992). $\mathrm{Cd}$ serves as a big concern to the ecosystem, because it has the ability to accumulate in living organism (Mohamed, 2008). Raissy et al. (2011) found the presence of $\mathrm{Cd}$ in the aquatic animals and ecosystem only in the range of trace concentrations. The concentration of $\mathrm{Cd}$ range in the ocean seawater from approximately (0.01-42) $\mu \mathrm{g} . \mathrm{l}^{-1}$ 


\section{Hashim \& Al-Yassein/ Basrah J. Agric. Sci., 33(2): 207-217, 2020}

(Soares et al., 2008). Over time the pollution affecting fish could cause dangerous human health problems by concentrated in an aquatic marine. (Authman et al., 2012). Environmental pollutants can induce oxidative stress in aquatic animals (Ceyhun $e t$ al., 2011), for example, $\mathrm{Cd}$ can cause hyperactivity and excitability in animals, which can lead to muscular fatigue. Muscle tissue can have direct contact with pollutants (Das \& Mukherjee, 2000). Cd also can cause several patho-morphological changes which can be showed in different tissues of aquatic fish. (Beširović et al., 2010).

Humans can be exposed to metals through many routs such as, lungs and skin, drinking contaminated water, and eating contaminated food (Wright \& Welbourn, 2002). The impact of $\mathrm{Cd}$ toxicity on human health showed on Minamata was Itai-Itai (Ouch-Ouch) Disease in Japanese people (Jintsu River Basin) with many symptoms such as complains of joint, bone, and muscle pains and severe kidney dysfunction (Landis et al., 2003; Bradl, 2005). Cd is toxic to humans when the daily intake is 250 to 300 micrograms (Wright \& Welbourn, 2002) and it is found highly persistent in humans, with a biological halflife of 20 to 30 years (Wright \& Welbourn, 2002; Landis et al., 2003).

Fish play an important role in human diet, because fishes are rich in omega-3 fatty acids, which are important to maintain balanced levels of blood glucose in the body (Qiu et al., 2011). In addition, it has an important nutrient, due to protein, iodine, different vitamins, minerals and necessary lipid compounds (Vieira et al., 2011). It has a big role in the food chain and is an important marker for many problems in aquatic ecosystems (Aktar et al., 2011). Nevertheless, the contaminated water could have negative effects on the function of the omega-3 fatty acids and protection human health against heart disease. (Ferreira et al., 2010). Among the many aquatic organisms, fish are considered a good indicator of the effects of pollutants absorbed (Shukla et al., 2007). The process of heavy metals storing in animals' tissue different among animals' types based on the kind of metal (Patnaik et al., 2011). The sublethal concentrations of $\mathrm{Cd}$ and lead can bioaccumulate in different tissues, which lead to damage and impaired physiology (Patnaik et al., 2011). The higher bioaccumulation rate was for $\mathrm{Cd}$ in fish tissues and many effects on tissue Histology (Vinodhini \& Narayanan, 2008). Ebrahimi \& Taherianfard (2011) show that the maximum concentrations of $\mathrm{Cd}$ in fish tissues were higher than the permissible levels for human consumption. Therefore, the study of fish tissues is an important mechanism to evaluate the health condition of the fish community. (McHugh et al., 2011). Heavy metals toxicity and muscles Histological changes in fishes have been reported by (Mohammed, 2009; Alak et al., 2013b; Begum et al., 2013; Badr et al., 2014).

Planiliza $a b u$ is an economically and ecologically important species as well as a human food. It has been detected through the basin of the Euphrates and Tigris rivers, as well as the Mediterranean basin of Southeastern Turkey (Jawad et al., 2015). Therefore, the objective of this study was to evaluate the effects of cadmium toxicity through the sublethal concentrations exposure and effects on Histo-pathological aspects of muscles structures on Juveniles of $P$. $a b u$.

\section{Materials \& Methods}

\section{Collection and Maintenance}

P. $a b u$ collected from marine science station aquariums. Fishes were acclimated under laboratory conditions at $23 \pm 1{ }^{\circ} \mathrm{C}$ and 4 psu 


\section{Hashim \& Al-Yassein/ Basrah J. Agric. Sci., 33(2): 207-217, 2020}

salinity in 10-gallon aquaria $(60 \times 30 \times 30)$ cm using a 14-h light: 12-h dark photoperiod. The Juveniles mean weight were (10.4-19.8) $\mathrm{g}$ and the mean length were $(9.6-18.4) \mathrm{cm}$. Water quality parameters were recorded every day throughout the acclimation period, including water temperature (thermometer) ${ }^{\circ} \mathrm{C}$, salinity (American Optics Refractometerpsu), dissolved oxygen (YSI Oxygen Meter Model \# Quatro Cable Assay, mg..$^{-1}$ ) and pH ( $\mathrm{pH}$ meter). Juveniles were daily fed Tetramin ${ }^{\circledR}$ Fish Flakes during lab acclimation but, were not fed during acute toxicity tests

\section{Preparing of concentration stock $\left(\mathrm{LC}_{50}\right)$}

The stock solution was made by solving (6.8466) $\mathrm{g}$ of aqueous cadmium sulfate $\left(\mathrm{CdSO}_{4} .8 \mathrm{H}_{2} \mathrm{O}\right)$ in one liter of distilled water that is equal to (1000) ppm. A required weight calculated according to the following equation: Molecular weight of a compound/ Atomic weight of the element $=$ weight of the compound required gm of per liter $\left(\mathrm{gm} . \mathrm{l}^{-1}\right)$.

\section{Calculating the median-lethal concentration}

Each aquarium $(60 \times 30 \times 30) \mathrm{cm}$ contained 15 animals with three replicates/ cadmium concentration and controls $(n=15$ fish/treatment) in each aquarium. Aqueous static renewal tests were conducted to determine 15days $\mathrm{LC}_{50}$ (median lethal concentration) the values concentrations for cadmium under laboratory conditions.

\section{Histo-pathological examination}

Parts of skeletal muscles from the control and experimental animals were taken from juveniles exposed to different concentrations of cadmium (0.5,1 and 2) ppm, fixed in Bouin's solution for $48 \mathrm{hrs}$. and dehydrated in a graded series of ethyl alcohol $(70 \%, 80 \%$, $90 \%, 95 \%$ and $100 \%$ ) then cleared in xylene and embedded in paraffin, and sectioned at 5 mm thick. Tissue stained with hematoxylineosin method (Humason, 1979) and examined by light microscopy according to Roberts (2001).

\section{Results}

Test conditions measured in the cadmium toxicity test are listed in (table 1). After 15 days of exposure there were differences in the toxicity of cadmium at all concentrations. Typically, mortality rate increase with increasing cadmium concentrations. For example, the mortality in $0.5,1$ and $2 \mathrm{ppm}$ were $(50 \%, 70 \%$ and $92 \%)$ respectively (table 2 ). The 15 days LC50 of cadmium was 0.405 ppm, (Fig. 1).

Plate (1) shows numerous Histopathological alterations in the muscles of $P$. $a b u$. juveniles exposed to different concentrations of cadmium. They are increased gradually with increasing $\mathrm{Cd}$ concentration. The pathological findings included marked thickening and hypertrophy in lowest concentration (0.5 ppm) , degeneration along with coagulative necrosis of muscle bundles have been reported in fish exposed to (1 ppm) of $\mathrm{Cd}$. however, muscle tissue showed atrophy, splitting, and separation with intracellular edema, at the highest concentration (2 ppm). 
Hashim \& Al-Yassein/ Basrah J. Agric. Sci., 33(2): 207-217, 2020

Table (1): Water quality conditions measured in cadmium toxicity tests.

\begin{tabular}{|l|c|}
\hline Water quality parameter & value measured \\
\hline Temperature & $23 \pm 1^{\circ} \mathrm{C}$ \\
\hline Salinity & $4 \mathrm{psu}$ \\
\hline $\mathrm{pH}$ & 7.7 \\
\hline Dissolved oxygen & $7.50 \mathrm{mg} . \mathrm{l}^{-1}$ \\
\hline
\end{tabular}

Table (2): Mortality $\%$ and $\mathrm{LC}_{50}$ for juveniles $P$. $a b u$ exposure to different concentrations of Cadmium (ppm) after 15days of exposure.

\begin{tabular}{|c|c|c|c|}
\hline Duration & Concentrations (ppm) & Mortality \% & LC $\mathbf{5 0}$ (ppm) \\
\hline \multirow{3}{*}{ 15-day } & 0.5 & $50 \%$ & 0.405 \\
\cline { 2 - 4 } & 1 & $70 \%$ & \\
\cline { 2 - 4 } & 2 & $92 \%$ & \\
\hline
\end{tabular}

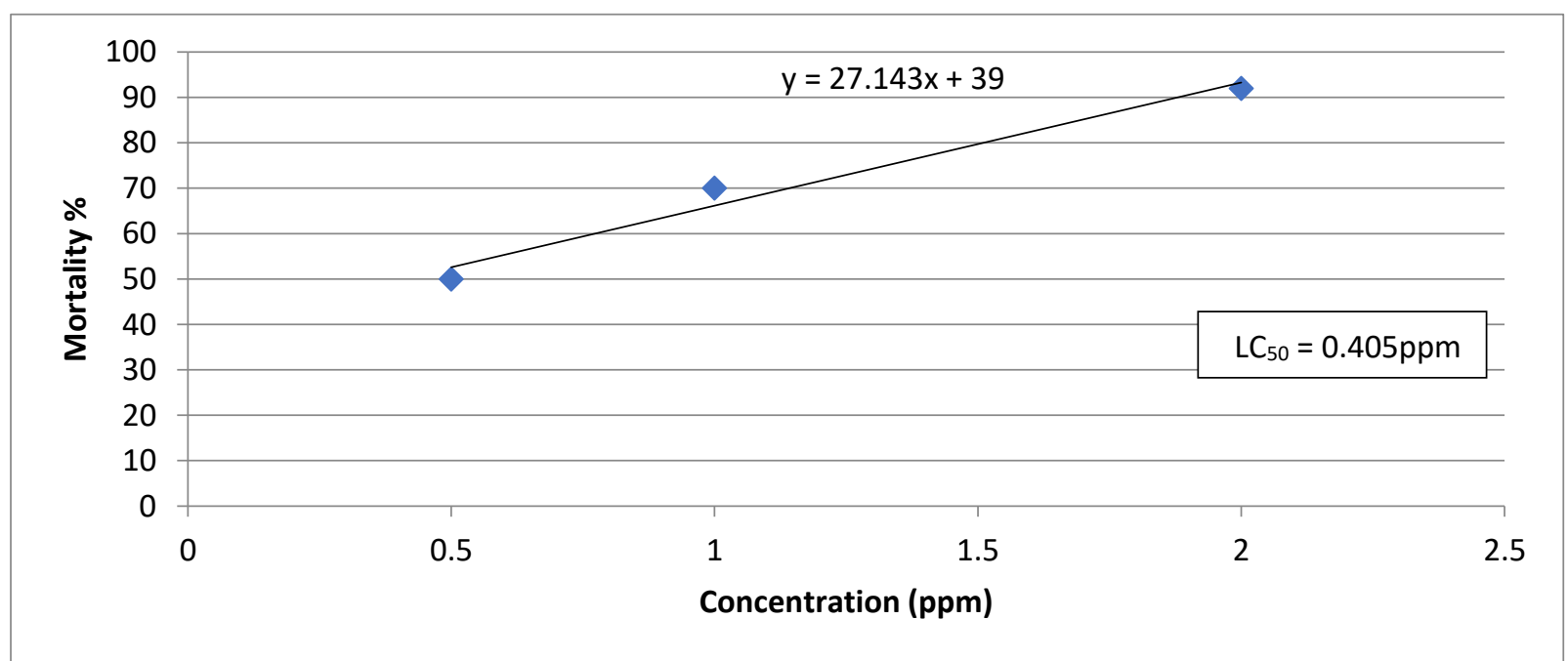

Fig. (1): Mortality percentage of $P$. $a b u$ Juveniles exposed to different concentrations after 15 days. 
Hashim \& Al-Yassein/ Basrah J. Agric. Sci., 33(2): 207-217, 2020
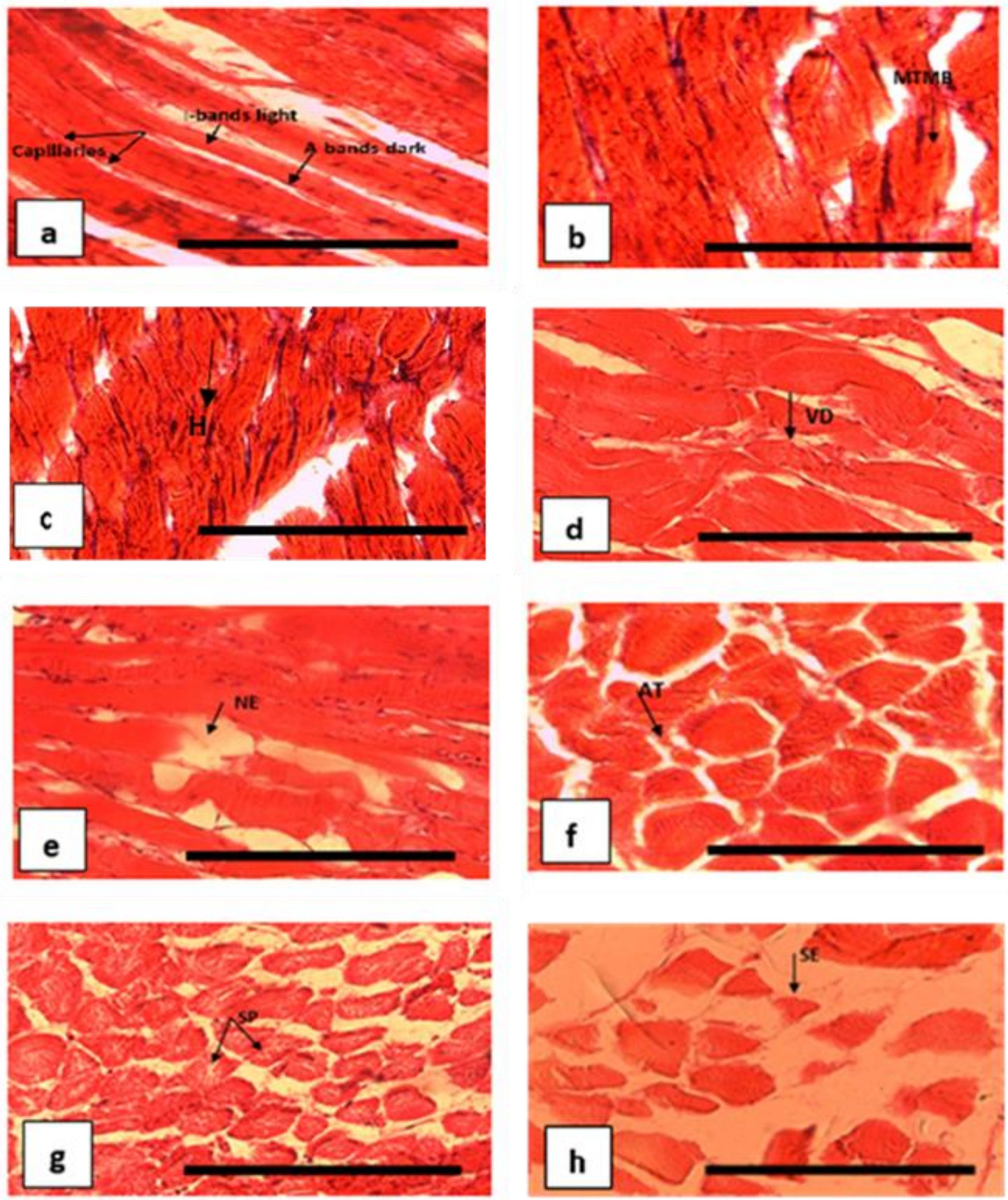

Plate (1): Photomicrograph of the normal structures of the skeletal muscle (Control) of $P$. $a b u$ showing; capillaries, bands light and bands dark; (b)\& (c) Photomicrographs of muscles (Cadmium treated 0.5) ppm showing; MTMB, marked thickening of muscle bundles , H, hypertrophy; (d),(e), Photomicrographs of muscles (Cadmium treated 1) ppm showing; VD, vacuolar degeneration, NC, coagulative necrosis; (f),(g),(h) Photomicrographs of muscles (Cadmium treated 2) ppm showing; AT, atrophy, SP, splitting, and SE, separation of the muscle bundles with intracellular edema . (H\&E). Scale Bar $=40 \mu \mathrm{m}$. 


\section{Hashim \& Al-Yassein/ Basrah J. Agric. Sci., 33(2): 207-217, 2020}

\section{Discussion}

The mortality percentage results of $P$. $a b u$ juveniles exposed to different concentrations of cadmium (0.5, 1 and 2) ppm were 50\%, $70 \%$ and $92 \%$ respectively (table 2 ). The 15 days LC50 of cadmium was $0.40 \mathrm{ppm}$ (figure1). This agrees with Hassan (2005) when exposed juvenile of Carassius carassius for 14 days to sublethal concentrations of $\mathrm{Cd}$ $(0.05 \& 0.5) \mathrm{ppm}$ the mortality percentage were $(70 \% \& 40 \%)$ respectively, while the LC50 was (0.35) ppm. Sobha et al. (2007) proved that mortality increase over the time, $\mathrm{LC}_{50}$ value of cadmium chloride for the fish Catla catla was $4.533 \mathrm{mg} . \mathrm{l}^{-1}$. Hassan (2011) observed the juvenile of common carp Cyprinus carpio exposed to sub-lethal concentrations of copper and cadmium (0.1, $0.25,0.4) \mathrm{ppm}$ led to decreased in survival rate with increasing concentration of copper from $50 \%$ to $10 \%$ and cadmium from $70 \%$ to $20 \%$ respectively.

Metals detrimental impact are evident in the environment, aquatic organisms and impairment of the ecological balance systems (Vosyliene \& Jankaite, 2006). Moreover, heavy metals could effect on the quality and quantity of fish stocks because of their effects on water quality, physiochemical characteristics and biological components (Mantovi et al., 2005; Singh et al., 2007). Heavy metals have adverse effects on aquatic organism including survival, activity, growth, metabolism and reproduction (Wright \& Welbourn, 2002). The aquatic organisms can be exposed to the heavy metals by many routes such as drinking water, eating contaminated sediment and other animals/ plants that have been exposed (Wright \& Welbourn, 2002). Therefore, fish and other aquatic organism can absorb dissolved metals in water and accumulate in tissues higher than in water, because metals undergo bioconcentration (Wright \& Welbourn, 2002). Heavy metals can accumulate in aquatic organisms including fish tissues more than the water concentration with a range up to 20,000-fold (Popek et al., 2006).

This study examined the Histological changes in fish muscles were increase gradually with $\mathrm{Cd}$ concentration including, marked thickening and hypertrophy in lowest concentration (0.5) ppm (plate 1). Exposure to the sublethal concentrations of cadmium recorded number of changes in the muscle's bundles including thickening and intramuscular oedema (Patnaik et al., 2011).

Exposure to the waterborne $\mathrm{Cd}$ in aquatic organism causes a significant accumulation of $\mathrm{Cd}$ in many organs like muscles (Alak et al., 2013b). Cd can accumulate in the aquatic animals through different routes such as food and water. It then binds to albumins and erythrocytes in blood, which can transfer it into different parts of the body (George et al., 1996; Karadeniz et al., 2009). Damage caused by heavy metals is an important cause of pathological and toxicological processes (Ates et al., 2008). In generally, Histopathological studies can be used as an indicator for determining the effects of heavy metals on aquatic organisms. (Bernet et al., 1999; Mohamed, 2009). The Histopathological alteration was caused by cadmium poisoning (Alak et al., 2013b).

However, in (1) ppm concentration was showed vacuolar degeneration and necrosis of muscle bundles. The results are in accordance with those obtained by (Mohamed, 2009). Different Histo-logical alterations were observed in the muscles of both fish effects of contaminated drainage water from Lake Qarun, Egypt on Coptodon zillii (= Tilapia zillii) and Solea vulgaris., which included 


\section{Hashim \& Al-Yassein/ Basrah J. Agric. Sci., 33(2): 207-217, 2020}

vacuolar degeneration and necrosis of muscle bundles. Histo-pathological examinations on the muscles were found at hypodermis of Nile tilapia Oreochromis niloticus and which included degeneration (myolysis) and arrangement exposed to different metals $(\mathrm{Cu}$, $\mathrm{Zn}, \mathrm{Cd}$ and $\mathrm{Pb}$ ) (Ibrahim et al., 2008). Several Histo-pathological alterations in muscle of two types of fish $O$. niloticus and Lates. niloticus, were discovered as a result of the accumulation of metals. One of the Histopathological alterations was degeneration in muscle bundles (Mohamed, 2008). Histological examination of $O$. niloticus muscles showed congestion associated with diffuse infiltration with inflammatory cells, hyperactivity of melanomacrographe centers around blood vessels, and focal area of necrosis (Badr et al., 2014).

On the other hand, the highest concentration (2) ppm was showed atrophy, splitting, and separation (plate 2). These results were confirmed with Begum et al. (2013) when exposed stinging catfish Heteropneustes fossilis exposed to (7.0 and 20.0) ppm of arsenic caused a significant increase in Histo-pathology of muscles bundle such as separation atrophy and splitting. Furthermore, when rainbow trout exposed to different sublethal concentrations ( 0.18 and $0.35) \mathrm{mg}^{-1}$ of lead caused a significant increase in Histo-pathology in muscles such as myocyte necrosis and atrophy (Alak et al., 2013a). While sublethal concentrations of cadmium caused intramuscular oedema (Patnaik et al., 2011). Brown trout were exposed to 2) ppm of cadmium can cause interstitial mononuclear cell infiltrations in muscle tissues. (Alak et al., 2013b). Some structural changes were observed due to lead acetate exposure, leading to space in muscular bundles and glomerular expansion in Clarias gariepinus (Al-Balawi et al., 2013). Exposure of Cyprinus carpio. to sublethal concentrations of cadmium after 28 days of exposure to (1.6) ppm has led to damage in fish muscles tissue Patnaik et al., 2011). After 60 days of exposure, there were partially damaged muscles, and slightly swollen/shortened villi (Begum et al., 2013). According to the Authman et al. (2012) exposed Nile tilapia (O. niloticus) to different concentrations of metals $(\mathrm{Al}, \mathrm{Cd}, \mathrm{Pb}, \mathrm{Hg}$ and $\mathrm{Ni}$, caused various Histo-pathological in muscles bundles.

The concentrations of cadmium in muscular tissue of $O$. niloticus and the concentrations in water, from contaminated fish farms, were (4.354 and 1.315) mg. $\mathrm{l}^{-1}$ respectively (Authman et al., 2012). The order of fishes tissues exposed to different concentrations of $\mathrm{Cd}$ were as follows: muscle < gill < liver < heart (Mohamed, 2008). Ibrahim et al. (2008) monitors the effects of metals on the biological, Histological and quality aspects of fish. The metals included $(\mathrm{Cu}, \mathrm{Zn}, \mathrm{Cd}$ and $\mathrm{Pb})$ on of fish O. niloticus and C. zillii. Authman et al. (2012) found that heavy metal levels in $O$. niloticus muscles were not possible range of human consumption.

\section{Conclusion}

The results were revealed that the mortality increases with increasing cadmium concentrations. Numerous of Histopathological changes of Planiliza $a b u$ Juveniles muscles have been noted. The Histological changes increased with increasing the concentration of the cadmium included, marked thickening and hypertrophy in lowest concentration (0.5 ppm) while atrophy, splitting, and separation, were observed in the tissues of fish muscles bundles at the highest concentration (2) ppm. Future studies should be including testing of 


\section{Hashim \& Al-Yassein/ Basrah J. Agric. Sci., 33(2): 207-217, 2020}

cadmium in different types of aquatic organism.

\section{Acknowledgements}

Authors are thankful to the Fisheries and Marine Resources department in Agriculture College of Basrah University for providing laboratory facilities during this study.

\section{References}

Abo El Ella, S. M., Hosny, M. M., \& Bakry, M. F. (2005). Utilizing fish and aquatic weeds infestation as bioindicators for water pollution in Lake Nubia, Sudan. Egyptian Journal of Aquatic Biology and Fisheries, 9: $63-$ 84.http://dx.doi.org/10.12944/CWE.7.2.15

Alak, G., Atamanalp, M., Topal, A., Arslan, H., Kocaman, E. M., \& Oruç, E. (2013a). Effect of sublethal lead toxicity on the histopathological and antioxidant enzyme activity of rainbow trout (Oncorhynchus mykiss). Fresenius Environmental Bulletin, 22(5), 733-738. https://www.researchgate.net/profile/Gonca_Alak/p ublication/316113119.

Alak, G., Atamanalp, M., Topal, A., Arslan, H., Oruç, E., \& Altun, S. (2013b). Histopathological and biochemical effects of humic acid against cadmium toxicity in brown trout gills and muscles. Turkish Journal of Fisheries and Aquatic Sciences, 13(2), 315-320.

https://www.researchgate.net/publication/27033818 0 .

Al-Balawi, H. F. A., Al-Akel, A. S., Al-Misned, F., Suliman, E. A. M., Al-Ghanim, K. A., Mahboob, S., \& Ahmad, Z. (2013). Effects of sub-lethal exposure of lead acetate on histopathology of gills, liver, kidney and muscle and its accumulation in these organs of Clarias gariepinus. Brazilian Archives of Biology and Technology, 56, 293-302. https://doi.org/10.1590/S1516-89132013000200015

Aktar, M. W., Sengupta, D., \& Chowdhury, A. (2011). Occurrence of heavy metals in fish: a study for impact assessment in industry prone aquatic environment around Kolkata in India. Environmental Monitoring and Assessment, 181, 51-61. https:// link.springer.com/article/10.1007/s10661-010$1812-\mathrm{x}$
Amdur, M.O., Doull, J., Curtis, M.D. \& Kloasen, C.D. (1992). Cassarett and Doull's Toxicology. Pergamon: The Basic Science of Poisons. New York/Oxford. (p. 996). https://doi.org/10.7326/0003-4819-117-5-448_2

Ates, B., Orun, I., Talas, Z. S., Durmaz, G., \& Yilmaz, I. (2008). Effects of sodium selenite on some biochemical and hematological parameters of rainbow trout (Oncorhynchus mykiss Walbaum, 1792) exposed to $\mathrm{Pb}^{2+}$ and $\mathrm{Cu}^{2+}$. Fish Physiology and Biochemistry, 34(1), 53-59. https://link.springer.com/article/10.1007\%2Fs1069 5-007-9146-5

Authman, M. M., Abbas, W. T., \& Gaafar, A. Y. (2012). Metals concentrations in Nile tilapia Oreochromis niloticus from illegal fish farm in AlMinufiya Province, Egypt, and their effects on some tissues structures. Ecotoxicology and Environmental Safety, 84, 163-172. https://doi.org/10.1016/j.ecoenv.2012.07.005

Badr, A. M., Mahana, N. A., \& Eissa, A. (2014). Assessment of heavy metal levels in water and their toxicity in some tissues of Nile Tilapia (Oreochromis niloticus) in River Nile basin at Greater Cairo, Egypt. Global Veterinaria, 13(4), 432-443.

https://doi.org/10.5829/idosi.gv.2014.13.04.8561

Bai, L. Y., Zeng, X. B., Li, L. F., Chang, P. E. N., \& Li, S. H. (2010). Effects of land use on heavy metal accumulation in soils and sources analysis. Agricultural Sciences in China, 9(11), 1650-1658. https://doi.org/10.1016/S1671-2927(09)60262-5

Begum, A., Mustafa, A. I., Amin, M. N., Banu, N., \& Chowdhury, T. R. (2013). Accumulation and histopathological effects of arsenic in tissues of shingi fish (Stinging Catfish) Heteropneustes fossilis (Bloch, 1794). Journal of the Asiatic Society of Bangladesh, Science, 39, 221-230. https://www.banglajol.info/index.php/JASBS/articl e/view/17861

Bernet, D., Schmidt, H., Meier, W., Burkhardt-Holm, P., \& Wahli, T. (1999). Histopathology in fish: proposal for a protocol to assess aquatic pollution. Journal of Fish Diseases, 22, 25-34. https://doi.org/10.1046/j.1365-2761.1999.00134.x

Beširović, H., Alić, A., Prašović, S., \& Drommer, W. (2010). Histopathological effects of chronic exposure to cadmium and zinc on kidneys and gills of brown trout (Salmo trutta morph. fario). Turkish 


\section{Hashim \& Al-Yassein/ Basrah J. Agric. Sci., 33(2): 207-217, 2020}

Journal of Fisheries and Aquatic Sciences, 10, 255262. https:// doi.org/ 10.4194/trjfas.2010.0214

Biswas, S., Prabhu, R. K., Hussain, K. J., Selvanayagam, M., \& Satpathy, K. K. (2012). Heavy metals concentration in edible fishes from coastal region of Kalpakkam, southeastern part of India. Environmental Monitoring and Assessment, 184, 5097-5104. https://link.springer.com/article/10.1007/s10661011-2325-y

Bradl, H. (Ed.). (2005). Heavy Metals in the Environment: Origin, Interaction and Remediation. Elsevier. Volume 6, Academic Press, 282pp. https://www.elsevier.com/books/heavy-metals-inthe-environment-origin-interaction-andremediation/bradl/978-0-12-088381-3

Ceyhun, S. B., Şentürk, M., Yerlikaya, E., Erdoğan, O., Küfrevioğlu, Ö. İ., \& Ekinci, D. (2011). Purification and characterization of carbonic anhydrase from the teleost fish Dicentrarchus labrax (European seabass) liver and toxicological effects of metals on enzyme activity. Environmental Toxicology and Pharmacology, 32, 69-74. https://doi.org/10.1016/j.etap.2011.03.013

Das, B. K., \& Mukherjee, S. C. (2000). A histopathological study of carp (Labeo rohita) exposed to hexachlorocyclohexane. Veterinarski Arhiv, 70, 169-180. http://wwwstaro.vef.unizg.hr/vetarhiv/papers/70-4/das.pdf.

Ebrahimi, M. \& Taherianfard, M. (2011). The effects of heavy metals exposure on reproductive systems of cyprinid fish from Kor River. Iranian Journal of Fisheries Sciences, 10, 13-26.http://jifro.ir/article1-121-en.html

Ferreira, M., Caetano, M., Antunes, P., Costa, J., Gil, O., Bandarra, N. \& Reis-Henriques, M. A. (2010). Assessment of contaminants and biomarkers of exposure in wild and farmed sea bass. Ecotoxicology and Environmental Safety, 73, 579588. https://doi.org/10.1016/j.ecoenv.2010.01.019

George, S. G., Todd, K. \& Wright, J. (1996). Regulation of metallothionein in teleosts: induction of MTmRNA and protein by cadmium in hepatic and extrahepatic tissues of a marine flatfish, the turbot (Scophthalmus maximus). Comparative Biochemistry and Physiology Part C: Pharmacology, Toxicology and Endocrinology, 113 , 109-115. https://doi.org/10.1016/07428413(95)02076-4
Hassan, B. K. (2005). The Effect of Sub Lethal Concentration of Cadmium on Gill and Liver of Carassian carp Carassius carassius (L.). M. Sc. Thesis, College of Agriculture, University of Basrah, 53pp. (In Arabic). link.springer.com/article/10.1007/s40011-0160806-z

Hassan, B. K. (2011). The effect of copper and cadmium on oxygen consumption of the juvenile common carp, Cyprinus carpio (L.). Mesopotamian Journal of Marine Science, 26, 25-34. DOI:10.21276/mjms

Humason, G. L. (1979). Animal Tissue Techniques. 4th edition, W.H. Freeman and company, San Francisco, CA, 661pp. https://www.abebooks.com/booksearch/isbn/9780716702993/

Ibrahim, S. M., Shalloof, K. A., \& Salama, H. M. (2008). Effect of environmental conditions of AbuZabal Lake on some biological, histological and quality aspects of fish. Global Veterinaria, 2, 257270.

https://www.researchgate.net/publication/23727827 1

Jawad, L., Bobori, D., Al-Shwikh, H., \& Al-Saleh, F. (2015). Opercular girth, maximum girth and total length relationships for Planiliza abu (Heckel, 1843) and Chondrostoma regium (Heckel, 1843) (Actinoprerygii) from Euphrates River at Dier EzZor Governorate, Syria. Acta Zoolgica. Bulgaria, 67 , http://acta-zoologicabulgarica.eu/downloads/acta-zoologicabulgarica/2015/67-4-591-594. pdf

Karadeniz, A., Cemek, M., \& Simsek, N. (2009). The effects of Panax ginseng and Spirulina platensis on hepatotoxicity induced by cadmium in rats. Ecotoxicology and Environmental Safety, 72, 231235. https://doi.org/10.1016/j.ecoenv.2008.02.021

Landis, W., Sofield, R., Yu, M. H. \& Landis, W. G. (2003). Introduction to Environmental Toxicology Impacts of Chemicals Upon Ecological Systems. Third edition, CRC Press, 512pp. https://books.google.iq/books/about/Introduction_to _Environmental_Toxicology.html?id=PNEtC_Z7P 8YC\&redir_esc $=y$

Mantovi, P., Baldoni, G., \& Toderi, G. (2005). Reuse of liquid, dewatered, and composted sewage sludge on agricultural land: effects of long-term application on soil and crop. Water Research, 39, 


\section{Hashim \& Al-Yassein/ Basrah J. Agric. Sci., 33(2): 207-217, 2020}

289-296

https://doi.org/10.1016/j.watres.2004.10.003

McHugh, K. J., Smit, N. J., Van Vuren, J. H. J., Van Dyk, J. C., Bervoets, L., Covaci, A., \& Wepener, V. (2011). A histology-based fish health assessment of the tigerfish, Hydrocynus vittatus from a DDTaffected area. Physics and Chemistry of the Earth, Parts $\quad A / B / C, \quad 36, \quad 895-904$. https://doi.org/10.1016/j.pce.2011.07.077

Mohamed, F. A. (2008). Bioaccumulation of selected metals and histopathological alterations in tissues of Oreochromis niloticus and Lates niloticus from Lake Nasser, Egypt. Global Veterinaria, 2, 205218.

http://citeseerx.ist.psu.edu/viewdoc/download?doi= 10.1.1. $499.3845 \&$ rep=rep1\&type=pdf

Mohamed, F. A. (2009). Histopathological studies on Tilapia zillii and Solea vulgaris from Lake Qarun, Egypt. World Journal of Fish and Marine Sciences, 1 , 29-39. http://citeseerx.ist.psu.edu/viewdoc/download?doi= 10.1.1.533.5081\&rep=rep $1 \&$ type $=$ pdf

Patnaik, B. B., Howrelia, H., Mathews, T., \& Selvanayagam, M. (2011). Histopathology of gill, liver, muscle and brain of Cyprinus carpio communis L. exposed to sublethal concentration of lead and cadmium. African Journal of Biotechnology, $\quad 10, \quad 12218-12223$. https://www.ajol.info/index.php/ajb/article/view/96 295

Popek, W., Dietrich, G., Glogowski, J., Demska-Zakeś, K., Drag-Kozak, E., Sionkowski, J., ŁuszczekTrojan, E., Epler, P., Demianowicz, W., Sarosiek, B., Kowalski, R., Jankun, M., Zakeś, Z., Król, J., Czerniak, S., \& Szczepkowski, M. (2006). Influence of heavy metals and 4-nonylphenol on reproductive function in fish. Reproductive Biology, 6, 175-188. https://europepmc.org/article/med/16967097

Qiu, Y. W., Lin, D., Liu, J. Q., \& Zeng, E. Y. (2011). Bioaccumulation of trace metals in farmed fish from South China and potential risk assessment. Ecotoxicology and Environmental Safety, 74, 284-293. https://doi.org/10.1016/j.ecoenv.2010.10.008

Raissy, M., Ansari, M., \& Rahimi, E. (2011). Mercury, arsenic, cadmium and lead in lobster (Panulirus homarus) from the Persian Gulf. Toxicology and
Industrial Health, 27, 655-659. https://doi.org/10.1177/0748233710395346

Roberts, R. J. (2001). Fish Pathology, Third edition. W. B. Saunders, Philadelphia, PA, 462pp. https://www.worldcat.org/title/fishpathology/oclc/45313495

Shukla, V., Dhankhar, M., Prakash, J., \& Sastry, K. V. (2007). Bioaccumulation of $\mathrm{Zn}, \mathrm{Cu}$ and $\mathrm{Cd}$ in Channa punctatus. Journal of Environmental Biology, 28, 395. http://www.jeb.co.in/journal_issues/200704_apr07_ supp/paper_07.pdf

Singh, R. K., Chavan, S. L., \& Sapkale, P. H. (2007). Heavy metal concentrations in water, sediments and body tissues of red worm (Tubifex spp.) collected from natural habitat Toxicology \& Pharmacology, 147(2), 168-178.s in Mumbai, India. Environmental Monitoring and Assessment, 129, 471-481. https://doi.org/10.1007/s10661-006-9377-4

Soares, S. S., Martins, H., Gutiérrez-Merino, C., \& Aureliano, M. (2008). Vanadium and cadmium in vivo effects in teleost cardiac muscle: metal accumulation and oxidative stress markers. Comparative Biochemistry and Physiology Part C: Toxicology \& Pharmacology, 147, 168-178. https://doi.org/10.1016/j.cbpc.2007.09.003

Sobha, K., Poornima, A., Harini, P., \& Veeraiah, K. (2007). A study on biochemical changes in the freshwater fish, Catla catla (Hamilton) exposed to the heavy metal toxicant cadmium chloride. Kathmandu University Journal of Science, Engineering and Technology, 3, 1-11. https://doi.org/10.3126/kuset.v3i2.2890

Taylor, M. D. (1997). Accumulation of cadmium derived from fertilizers in New Zealand soils. Science of the Total Environment, 208(1-2), 123126. https://doi.org/10.1016/S0048-9697(97)002738

Vieira, C., Morais, S., Ramos, S., Delerue-Matos, C., \& Oliveira, M. B. P. P. (2011). Mercury, cadmium, lead and arsenic levels in three pelagic fish species from the Atlantic Ocean: Intra-and inter-specific variability and human health risks for consumption. Food and Chemical Toxicology, 49, 923-932. https://doi.org/10.1016/j.fct.2010.12.016

Vinodhini, R., \& Narayanan, M. (2008). Bioaccumulation of heavy metals in organs of freshwater fish Cyprinus carpio (Common carp). International Journal of Environmental Science \& 


\title{
Hashim \& Al-Yassein/ Basrah J. Agric. Sci., 33(2): 207-217, 2020
}

Technology,

5 ,

179-182.

https://link.springer.com/article/10.1007\%252FBF0 3326011

Vosylienè, M. Z., \& Jankaite, A. (2006). Effect of heavy metal model mixture on rainbow trout biological parameters. Ekologija, 4, 12-17. https://vb.gamtc.lt/object/elaba:6213167/
Wright, D. A., \& Welbourn, P. (2002). Environmental Toxicology (Vol. 11). Cambridge University Press, 630pp.

https://books.google.iq/books/about/Environmental _Toxicology.html?id=F8y12B3gIbkC\&redir_esc=y

تأثير التراكيز تحت المميتة للكادميوم على التغيرات المرضية النسيجية لعضلات يافعات اسماك الخشني Planiliza abu (Heckel, 1843)

\author{
انتصار شعبان هاشم و رجاء نوري الياسين \\ قسم الاسماك و الثروة البحرية، كلية الزر اعة، جامعة البصرة، العراق
}

المستخلص: تلوث المياه بالمعادن قضية عالمية، بسبب تأثيره الضار على البيئة و الكائنات المائية وضعف نظم التوازن البيئي.

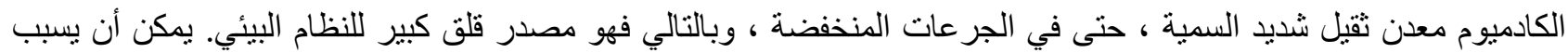

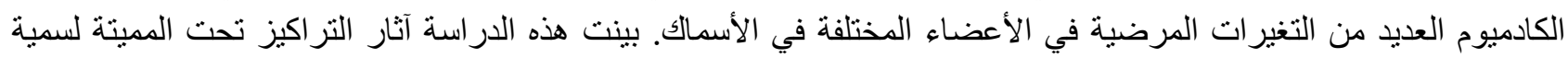
الكادميو و آثار ها على الأنسجة المرضية للأنسجة العضلية على يافعات الخشني Planiliza abu. كانت تر اكيز الكادميوم تتر اوح

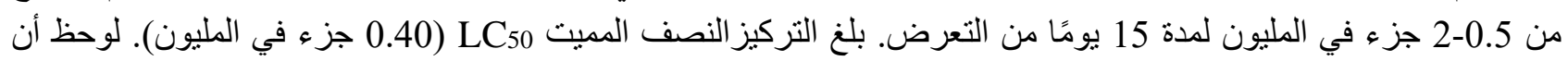

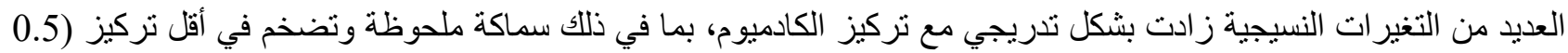

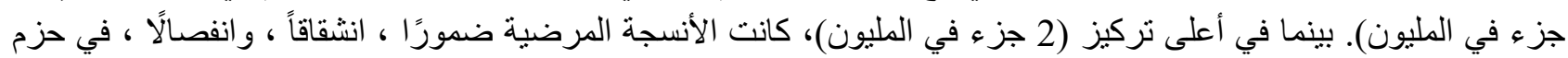
عضلات. الكلمات المفتاحية: الخشني Planiliza abu، الكادميوم، تركيزات تحت المينة. عضلات، أمر اض نسيجية. 